\title{
Physical changes within a large tropical hydroelectric reservoir induced by wintertime cold front activity
}

\author{
M. P. Curtarelli ${ }^{1}$, E. H. Alcântara ${ }^{1}{ }^{*}$, C. D. Rennó ${ }^{1}$, and J. L. Stech ${ }^{1}$ \\ ${ }^{1}$ National Institute for Space Research, São José dos Campos, São Paulo, Brazil \\ * now at: São Paulo State University, Presidente Prudente, São Paulo, Brazil \\ Correspondence to: M. P. Curtarelli (mpedroso@dsr.inpe.br)
}

Received: 7 June 2013 - Published in Hydrol. Earth Syst. Sci. Discuss.: 2 July 2013

Revised: 7 July 2014 - Accepted: 10 July 2014 - Published: 20 August 2014

\begin{abstract}
We investigated the influence of wintertime cold front activity on the physical processes within a large tropical reservoir located in Brazil. The period chosen for this study consisted of 49 days between 28 April 2010 and 15 July 2010. This period was defined based on information from the Brazilian Center for Weather Forecasting and Climate Studies (CPTEC), data collected in situ and the interpretation of remotely sensed images. To better understand the governing processes that drive changes in the heat balance, differential cooling and mixing dynamics, a simulation was performed that utilized a three-dimensional hydrodynamic model enforced with in situ and remote sensing data. The results showed that during a cold front passage over the reservoir, the sensible and latent heat fluxes were enhanced by approximately 77 and $16 \%$, respectively. The reservoir's daily averaged heat loss was up to $167 \%$ higher on the days with cold front activity than on the days without activity. The cold front passage also intensified the differential cooling process; in some cases the difference between the water temperature of the littoral and pelagic zones reached up to $8^{\circ} \mathrm{C}$. The occurrence of cold front passages impacted the diurnal mixed layer (DML), by increasing the turbulent energy input $(\sim 54 \%)$ and the DML depth $(\sim 41 \%)$. Our results indicate that the cold front events are one of the main meteorological disturbances driving the physical processes within hydroelectric reservoirs located in tropical South America during the wintertime. Hence, cold front activity over these aquatic systems has several implications for water quality and reservoir management in Brazil.
\end{abstract}

\section{Introduction}

Physical processes that occur within reservoirs, such as mixing and differential cooling, are mainly controlled by momentum and energy exchanges with the atmosphere, inflowing rivers and offtake discharges (Imberger, 1985; Imberger and Patterson, 1989). Mixing of the water column is related to important biogeochemical processes that occur inside the reservoirs, influencing the carbon cycle (Eugster et al., 2003), nutrient fluxes (MacIntyre et al., 1999) and the phytoplankton distribution (Serra et al., 2007; Curtarelli et al., 2014). Although several studies describe the physical dynamics and main driving forces in lakes and reservoirs (Imberger and Patterson, 1989; MacIntyre et al., 2002; Wüest and Lorke, 2003), few studies have addressed this issue for tropical South America reservoirs, which are subject to local weather conditions that vary throughout the year and frequent meteorological disturbances, such as cold front incursions.

Cold front incursions are one of the most recurrent synoptic patterns over South America; they greatly affect atmospheric circulation, precipitation and temperature regimes (Garreaud, 2000). These events occur year-round and reach the Brazilian territory every 1-2 weeks; however, they are more frequent during the austral winter (Stech and Lorenzzetti, 1992). Winter cold fronts are also more severe and can cause freezing temperatures in southern and southeastern Brazil (Marengo et al., 2002). The majority of these fronts reach the hinterlands of São Paulo, Minas Gerais and Goiás where many reservoirs are located; most of these reservoirs are used for generating energy. 
A preliminary investigation performed by Alcântara et al. (2010a) in the Itumbiara Hydroelectric Reservoir (IHR), which is located in central Brazil, showed that during a single cold front passage, the reservoir heat loss tends to increase in response to the changing weather conditions. This study also demonstrated that the cold front passage contributed to water column destabilization and promoted vertical mixing. Nevertheless, this study was limited because it was based on punctual measurements via a monitoring buoy located near the dam. Thus, the estimates of the heat fluxes obtained by Alcântara et al. (2010a) may not be representative of the entire lake and likely vary spatially with limnological (e.g., warmer nearshore water temperatures) and meteorological conditions over such a large reservoir. In addition, the sensible and latent heat fluxes were estimated without considering the stability of the atmospheric boundary layer (ABL), which is persistently unstable over tropical reservoirs (Verburg and Antenucci, 2010) and leads to underestimated heat fluxes.

Three-dimensional (3-D) models are complementary and efficient approaches that have been widely used for understanding physical and biological processes in lakes and reservoirs (Bonnet and Wessen, 2001; Hodges et al., 2002; Vidal et al., 2007; Rueda and MacIntyre, 2009; Okely et al., 2010). One of the main advantages of 3-D models is the possibility to simulate real and hypothetical scenarios, as well as the ability to simulate various processes simultaneously. Conversely, one of the major disadvantages of this approach is the large amount of input data and parameters needed, which often limits its use.

In this study, we investigated the effects of winter cold front passages on the heat balance, differential cooling and DML (diurnal mixed layer) dynamics of the IHR. To complement the findings of Alcântara et al. (2010a), which were based on single-point measurements, we used a 3-D hydrodynamic model to simulate the physical response of the IHR under actual winter cold front conditions. We used in situ and remote-sensing-derived measurements (i.e., cloud cover, rainfall rate and inflow water temperature) as input data into the model. Due to the persistent unstable conditions over tropical lakes and reservoirs (Verburg and Antenucci, 2010), we considered the stability of the ABL during the simulation. Our main goals were to identify the typical diel behavior of the heat balance components and the DML dynamics at the beginning of the austral winter and to evaluate the impacts of cold front passages on these processes.

\section{Site description}

The IHR is located in the Paraná River basin $\left(18^{\circ} 25^{\prime} \mathrm{S}\right.$, $49^{\circ} 06^{\prime} \mathrm{W}$ ) on the border of the Minas Gerais and Goiás states, central Brazil (Fig. 1a). The reservoir was formed by damming the Paranaíba River, which resulted in the flooding of its main tributaries, i.e., the Corumbá River and Araguari River. The Itumbiara regional geomorphology resulted in a

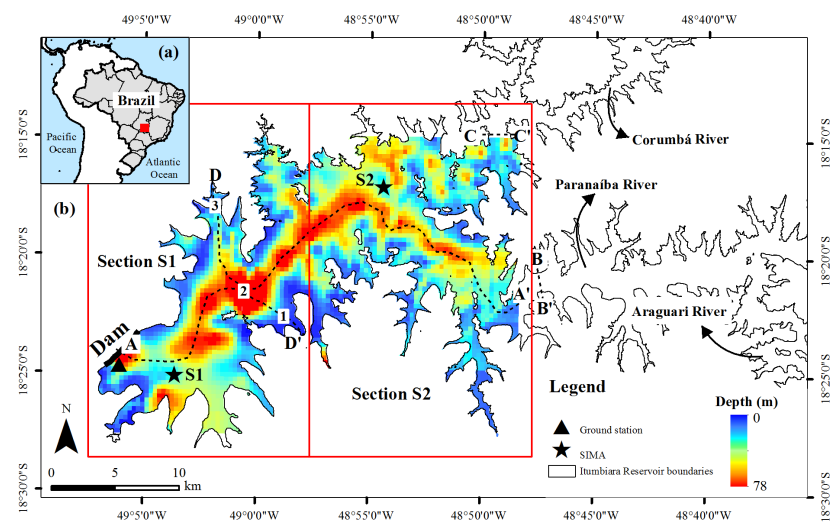

Figure 1. Location of the Itumbiara Reservoir in central Brazil (a) and its detailed boundaries and bathymetry (b).

lake with a dendritic pattern covering an area of approximately $778 \mathrm{~km}^{2}$ and a volume of 17.03 billion $\mathrm{m}^{3}$ (Fig. 1b). The reservoir's surface is located $520 \mathrm{~m}$ above sea level (ma.s.l). The major axis is $30 \mathrm{~km}$ long, and the maximum width is approximately $15 \mathrm{~km}$. The reservoir depth ranges from 0.5 to $78 \mathrm{~m}$, with a mean depth of $32 \mathrm{~m}$.

According to the Köppen-Geiger classification system (Peel et al., 2007), the climate in the Itumbiara Reservoir region is classified as "tropical savanna" with two well-defined seasons: dry (May-October) and wet (December-April). The monthly precipitation ranges from $5 \mathrm{~mm}$ in the peak of the dry season (winter in the Southern Hemisphere) to $250 \mathrm{~mm}$ in the peak of the wet season (summer in the Southern Hemisphere). The average air temperature is higher during the wet season $\left(24-26^{\circ} \mathrm{C}\right)$ and decreases during the dry season; the temperature can be lower than $20^{\circ} \mathrm{C}$ in July. The relative humidity displays a pattern similar to that of the air temperature but with a small shift in the minimum value toward September $(47 \%)$. The mean wind intensity is lower during the wet season $\left(1.6 \mathrm{~m} \mathrm{~s}^{-1}\right)$ than during the dry season $\left(3.3 \mathrm{~m} \mathrm{~s}^{-1}\right)$. On average, 11 cold fronts pass over the reservoir annually; approximately $75 \%$ of the occurrences are during the dry season (Curtarelli, 2012). May and September experience the highest frequencies of cold front passages, with an average of two passages each. Depending on its intensity, a cold front can remain over the Itumbiara Reservoir for up to 5 days (Curtarelli, 2012).

\section{Data and methods}

\subsection{Reservoir bathymetry}

The bathymetry of the Itumbiara Reservoir was derived from depth samples collected with an LMS-525 Lowrance ${ }^{\circledR}$ ecobathymeter (Tulsa, OK, USA) during two field campaigns conducted in May and August 2009. A total of 125631 depth samples with an accuracy of $\pm 0.1 \mathrm{~m}$ were collected during 
the two field campaigns. The bathymetric grid, which has a spatial resolution of $150 \mathrm{~m} \times 150 \mathrm{~m}$, was obtained by interpolating the depth samples using an ordinary Kriging algorithm (Bailey and Gretel, 1995) following the approach described by Merwade (2009). The depth values were corrected to the maximum level of the reservoir operation (520 $\mathrm{m}$ a.s.l).

\subsection{In situ data set}

The in situ data set included meteorological, limnological and fluviometric data. The meteorological data were acquired hourly by two autonomous systems called "SIMA" (Integrated System for Environmental Monitoring) that were anchored within the reservoir (see the location in Fig. 1). The SIMA (Stech et al., 2006; Alcântara et al., 2013) is a set of hardware and software designed for meteorological and limnological data acquisition and real-time monitoring of natural and artificial aquatic systems (Table 1). Throughout this study, the SIMA located near the dam is called station S1, while the station anchored near the river-reservoir transition zone is called station $\mathrm{S} 2$.

Water temperature data at different depths were collected by thermistor chains coupled to the SIMA. The S1-coupled thermistor chain collected temperature data at five depths (1, $5,12,20$ and $40 \mathrm{~m}$ ), while the S2-coupled thermistor chain collected temperature data at three depths $(5,12$ and $20 \mathrm{~m})$. The thermistors are accurate to $\pm 0.20^{\circ} \mathrm{C}$ and have a response time of $2.5 \mathrm{~s}$. Water temperature data were also collected hourly and sent via a satellite downlink to a ground station in near-real-time.

Time series of total inflow, outflow and water level were provided with daily frequency by Eletrobras-Furnas, which is the company that oversees the IHR operation. The total inflow was divided between the two main tributaries (Paranaíba and Corumbá rivers) based on the outflow time series of the Corumbá Reservoir, which is located in the Corumbá River $35 \mathrm{~km}$ upstream of the Itumbiara Reservoir, and flow data measured in small tributaries of Corumbá River. The Corumbá River inflow was considered to equal the outflow of the Corumbá Reservoir plus the flow of its small tributaries. The Paranaíba River inflow was calculated by subtracting the Corumbá River inflow from the total inflow. We estimated that $77 \%$ of the total inflow is attributed to the Paranaíba River, and $23 \%$ is attributed to the Corumbá River. Then, the total inflow data were distributed between the two inflows using the percentages indicated above.

\subsection{Satellite data set}

The satellite-based data set included cloud cover fraction, the water surface temperatures (WSTs) of the rivers' inflows and the daily precipitation rates over the Itumbiara Reservoir. The cloud cover fraction and WST of the river inflows were retrieved using data collected by the Moderate Resolution Imaging Spectroradiometer (MODIS) (Justice et al.,
1998), while the daily precipitation rates were retrieved using data collected by the Tropical Rainfall Measuring Mission (TRMM) (Kummerow et al., 1998). These data are presented in more detail in the following sections.

\subsubsection{WST of river inflows}

The WSTs of river inflows were retrieved using the M*D11A1 product (Wan, 2008). The M*D11A1 is a standard product that is generated using a split-window algorithm and seven spectral MODIS bands in the shortwave infrared and thermal infrared regions. This algorithm is based on the differential absorption of adjacent bands in the infrared region (Wan; Dozier, 1996). The M*D11A1 products have been validated at stage 2 via a series of field campaigns conducted between 2000 and 2007 and at additional locations and time periods through radiance-based validation studies. The accuracy is better than $1{ }^{\circ} \mathrm{C}\left(0.5^{\circ} \mathrm{C}\right.$ in most cases $)$ as was expected prelaunch. This product is generated up to four times each day (i.e., 10:30, 13:30, 23:30 and 01:30 LT) and is delivered in a georeferenced grid with a $1 \mathrm{~km}$ spatial resolution in a sinusoidal projection.

The M*D11A1 product was acquired online and preprocessed using the MODIS Reprojection Tool. The data were first resampled to a $150 \mathrm{~m}$ spatial resolution (compatible with the bathymetric grid). Then, they were reprojected to the Universal Transverse Mercator (UTM) coordinate system (zone 22 South) with the World Geodetic System (WGS-84) datum as a reference and converted to a raster image. Lastly, a MATLAB ${ }^{\circledR}$ program was used for retrieving the WSTs at the river inflows. To compute the WST of each river, we considered only the temperature values of the pixels located in the transect BB' (Paranaíba River) and transect CC' (Corumbá River; see Fig. 1). To avoid erroneous values of WST near the river edges due to land contamination, we used a subpixel temperature-retrieving (SPTR) approach (Setlinger et al., 2008) to extract the WST. The WSTs of river inflows obtained using the $\mathrm{M}^{*} \mathrm{D} 11 \mathrm{~A} 1$ product were compared to the data acquired by the thermistor chain coupled to the S2 station in the river-reservoir transition zone; the data sets exhibited a good correlation with the observed temperature $\left(R^{2}>0.88\right)$.

\subsubsection{Cloud cover fraction}

The cloud cover fraction over the IHR was retrieved using the MODIS Level 2 Cloud Mask product (named M*D35L2) (Ackerman et al., 1998). The algorithm used for generating this product employs a series of visible and infrared thresholds and consistency tests to obtain a confidently unobstructed view of Earth's surface. This product is generated up to four times each day (i.e., 10:30, 13:30, 23:30 and 01:30 LT) and is delivered in a georeferenced grid with a $1 \mathrm{~km}$ spatial resolution in a sinusoidal projection. 
Table 1. Technical specification of the SIMA sensors.

\begin{tabular}{llllr}
\hline Sensor & Manufacturer & Range & Accuracy & Height \\
\hline Air temperature & Rotronic & -4 to $60^{\circ} \mathrm{C}$ & $\pm 0.3^{\circ} \mathrm{C}$ & 3 \\
Wind speed & Young & $0-100 \mathrm{~m} \mathrm{~s}^{-1}$ & $\pm 0.3 \mathrm{~m} \mathrm{~s}^{-1}$ & 3 \\
Wind direction & Young & $0-360$ & $\pm 3^{\circ}$ & 3 \\
Relative humidity & Rotronic & $0-100 \%$ & $\pm 1 \%$ & 3 \\
Shortwave radiation & Novalynx & $0-1500 \mathrm{~W} \mathrm{~m}{ }^{-2}$ & $<1 \mathrm{~W} \mathrm{~m}^{-2}$ & 3 \\
Barometric pressure & Vaisala & $800-1060 \mathrm{hPa}$ & $\pm 0.3 \mathrm{hPa}$ & 3 \\
\hline
\end{tabular}

The $\mathrm{M} * \mathrm{D} 35 \mathrm{~L} 2$ product was acquired online and preprocessed using the MODIS Reprojection Tool. The data were first resampled to a $150 \mathrm{~m}$ spatial resolution (compatible with the bathymetric grid). Then, the data were reprojected to the UTM coordinate system (zone 22 south), using the WGS-84 datum as a reference, and converted to a raster image. Afterward, a MATLAB ${ }^{\circledR}$ routine was used for computing the cloud cover fraction over the reservoir.

\subsubsection{Daily precipitation rate}

The daily precipitation rate over the Itumbiara Reservoir was obtained using the TRMM 3B42 product (Huffman et al., 2007) version 6 , which provides daily accumulated precipitation rates in a georeferenced grid with a $25 \mathrm{~km}$ resolution. The TRMM 3B42 product has been validated through the ground validation $(\mathrm{GV})$ program at NASA Goddard Space Flight Center in Greenbelt, Maryland, which is responsible for processing several TRMM science products for validating space-based rain estimates of the TRMM satellite. The 3B42 product satisfactorily reproduces the surface observationbased histogram of precipitation and reasonably detects large daily events. The precipitation time series over the IHR was generated using the TRMM Online Visualization and Analysis System (TOVAS).

\subsection{Numerical modeling of heat balance and thermal structure}

\subsubsection{Model description}

The Estuary and Lake Computer Model (ELCOM) (Hodges et al., 2000) was used for simulating the physical response of the IHR to the winter cold front passages. ELCOM solves unsteady, coupled, Reynolds-averaged Navier-Stokes equations and scalar transport equations using hydrostatic and Boussinesq approximations to model the velocity, salinity and temperature of water in 3-D space and time. The hydrodynamic algorithms that are implemented in ELCOM use an Euler-Lagrange approach for the advection of momentum adapted from Casulli and Cheng (1992), while the advection of scalars is based on the ULTIMATE QUICKEST method proposed by Leonard (1991).
The thermodynamics model considers the penetrative and nonpenetrative components (Hodges et al., 2000). The fraction of $Q_{\mathrm{sw}}(280$ to $2800 \mathrm{~nm}$ ) that penetrates the water body, $Q_{\mathrm{sw}}^{(-0)}$, is given by

$Q_{\mathrm{sw}}^{(-0)}=Q_{\text {sw_total }}\left(1-r_{\mathrm{a}}^{\mathrm{sw}}\right)$,

where $Q_{\text {sw_total }}$ is the total incident shortwave radiation over the water surface and $r_{\mathrm{a}}^{\mathrm{sw}}$ is the albedo of water for shortwave radiation. ELCOM allows the user to divide the $Q_{\text {sw_total }}$ into four components: photosynthetically active radiation (PAR), near-infrared and ultraviolet (A and $\mathrm{B}$ ) radiation; the attenuation through the water column follows the Beer-Lambert law:

$Q_{\mathrm{sw}}(z)=Q_{\mathrm{sw}}^{(-0)} e^{-\eta_{\mathrm{a}} z}$,

where $z$ is the depth below the water surface $(\mathrm{m})$ and $\eta_{\mathrm{a}}$ is the shortwave attenuation coefficient $\left(\mathrm{m}^{-1}\right)$. The net $Q_{\mathrm{lw}}$ can be estimated as function of the cloud cover fraction, $C$, as follows:

$Q_{\mathrm{lw}}=\left(1-r_{\mathrm{a}}^{(\mathrm{lw})}\right)\left(1+0.17 C^{2}\right) \varepsilon_{\mathrm{a}} \sigma T_{\mathrm{a}}^{4}-\varepsilon_{\mathrm{s}} \sigma T_{\mathrm{s}}^{4}$,

where $r_{\mathrm{a}}^{(1 \mathrm{w})}$ is the water albedo for the longwave radiation, $\varepsilon_{\mathrm{a}}$ is the air emissivity, $\sigma$ is the Stefan-Boltzmann constant (i.e., $\left.5.6697 \times 10^{-8} \mathrm{~W} \mathrm{~m}^{-2}, \mathrm{~K}^{-4}\right), T_{\mathrm{a}}$ is the air temperature (K), $\varepsilon_{\mathrm{S}}$ is the water emissivity (i.e., 0.96 ), and $T_{\mathrm{S}}$ is the water surface temperature (K). $Q_{\text {sh }}$ and $Q_{\mathrm{lh}}$ are estimated by standard bulk transfer models and are parameterized as functions of meteorological variables as described by Fischer et al. (1979):

$Q_{\mathrm{sh}}=C_{\mathrm{sh}} \rho_{\mathrm{a}} C_{p} U_{10}\left(T_{\mathrm{a}}-T_{\mathrm{s}}\right)$,

$Q_{\mathrm{lh}}=\frac{0.622}{p} C_{\mathrm{lh}} \rho_{\mathrm{a}} L_{\mathrm{E}} U_{10}\left(e_{\mathrm{a}}-e_{\mathrm{s}}\right)$,

where $C_{\mathrm{sh}}$ is the transfer coefficient for sensible heat flux, $\rho_{\mathrm{a}}$ is the air density $\left(\mathrm{kg} \mathrm{m}^{-3}\right), C_{p}$ is the specific heat of air at a constant pressure $\left(=1003 \mathrm{~J} \mathrm{~kg}^{-1} \mathrm{~K}^{-1}\right), U_{10}$ is the wind speed $\left(\mathrm{m} \mathrm{s}^{-1}\right)$ at the standard reference height of $10 \mathrm{~m}, p$ is the atmospheric pressure (Pa), $C_{\mathrm{lh}}$ is the transfer coefficient for latent heat flux, $e_{\mathrm{a}}$ is the vapor pressure of the air $(\mathrm{Pa})$, and $e_{\mathrm{s}}$ is the saturation vapor pressure (Pa) at $T_{\mathrm{s}}$. ELCOM does not consider the condensation effects in its formulation. 
Furthermore, ELCOM allows the user to simulate the effects of atmospheric stability on the surface heat fluxes using the iterative procedure proposed by Hicks (1975) and described by Imberger and Patterson (1989). In this case, the extrapolation of meteorological data collected at a given height above the water surface to the $10 \mathrm{~m}$ standard reference height is performed following Rayner (1981).

The vertical mixing model uses the transport equations of turbulent kinetic energy (TKE) to compute the energy available from stirring and shear mechanisms for the mixing process (Spiegel and Imberger, 1980). The energy required to induce vertical mixing is given by the density gradient in the water column. The wind energy available for mixing, $E_{\text {wind }}$, is parameterized as a function of the water shear velocity, $u w^{*}$, and a mixing coefficient, $C_{n}(=1.33)$, as follows:

$E_{\text {wind }}=\frac{1}{2} C_{n}^{3} u w^{* 3}$.

The shear energy, $E_{\text {shear }}$, is parameterized as a function of shear, $S$, and another mixing coefficient, $C_{S}(=0.15)$, as follows:

$E_{\text {shear }}=\frac{1}{2} C_{S} S^{2}$.

A complete description of the formulae and numerical methods used in ELCOM was presented by Hodges et al. (2000).

\subsubsection{Period of simulation}

The period of 6 May 2010-15 July 2010 was chosen to simulate the cold front passage effects on the heat budget and on the DML dynamics of the IHR. This period was chosen based on the availability of reliable in situ and remote sensing data and the occurrence of cold front passages. According to the CPTEC (Center for Weather Forecasting and Climate Studies), five cold fronts (hereafter referred to as F1, F2, F3, F4 and F5) passed over the Itumbiara region during the period. These five cold front passages were confirmed by analyzing the meteorological data collected in situ and from satellite images (Fig. 2) obtained by the Geostationary Operational Environmental Satellite (GOES).

\subsubsection{Model setup, sensitivity analysis and validation}

The numerical domain, which was based on the bathymetry data availability, was discretized in a uniform horizontal grid containing $150 \mathrm{~m} \times 150 \mathrm{~m}$ cells. To investigate the DML dynamics, we used a nonuniform vertical grid resolution with thin layers in the upper part of the water column. The thickness of the vertical layers increased smoothly with the depth from $0.1 \mathrm{~m}$ (upper water column) to $5 \mathrm{~m}$ (bottom layer), resulting in a total of 67 layers. This grid configuration was chosen to optimize the model performance and to reduce the computational cost (Hodges and Dallimore, 2010). The water albedo for shortwave radiation was set to 0.03 (Slater, 1980),



Figure 2. Cloudiness associated with cold front passages over the Itumbiara Reservoir observed by GOES. False color composites (R2G3B1) during the F1 (a-d), F2 (e-h), F3 (i-l), F4 (m-p) and F5 (q-t) passages.

and the bottom drag coefficient was set to 0.001 (Wüest and Lorke, 2003). The attenuation coefficient for PAR was set to $0.6 \mathrm{~m}^{-1}$ based on Secchi disc measurements performed in the Itumbiara Reservoir during a field survey conducted in May 2009. A value of $5.25 \mathrm{~m}^{2} \mathrm{~s}^{-1}$ (Pacheco et al., 2011) was chosen for the horizontal diffusivity of temperature and for the horizontal momentum.

Due to the presence of persistent unstable atmospheric conditions over tropical reservoirs (Verburg and Antenucci, 2010), the atmospheric stability submodel was activated during the simulation; this procedure is appropriate for cases in which the meteorological sensors are located within the internal boundary layer over the surface of the lake and data are collected at subdaily intervals (Imberger and Patterson, 1989). The stability of the ABL is evaluated through the stability parameter, which is derived from the Monin-Obukhov length scale. ELCOM uses the similarity functions presented in Imberger and Patterson (1989) for both stable and unstable conditions. Taking into account the results obtained by Curtarelli et al. (2013a), we considered the rotational effects of Earth during the simulations. 
Three sets of boundary cells that force the inflow and outflow are defined: two inflows (the Corumbá and Paranaíba rivers) and one outflow (the water intake at the bottom of the dam). The free surface of the reservoir was divided into two sections: one section was under the influence of S1, and the other section was under the influence of the S2 meteorological data set (see the two sections in Fig. 1). The model was forced using hourly meteorological data acquired by the two SIMAs, the daily inflow and outflow provided by EletrobrasFurnas, the cloud cover and river temperatures extracted from the MODIS products and the daily precipitation provided by the TRMM 3B42 product (Fig. 3).

To provide realistic estimates, the simulation was initiated 8 days before the period of interest to spin up the circulation patterns and water temperature gradient (see Fig. 3). The simulation began on 28 April 2010 at 23:30 LT (local time) and ended on 15 July 2010 at 23:30 LT. All of the times used in this work refer to the local time (-3 GMT, Greenwich Mean Time). The simulation was programmed to run at efficient time steps with the Courant-Friedrichs-Lewy number fixed at 1/3 (Hodges et al., 2006). Thus, the time step was set to $150 \mathrm{~s}$, which was sufficient to ensure the numerical stability of the model (Cassuli and Cattani, 1994). The initial temperature profiles were obtained through linear interpolation from S1- and S2-coupled thermistor chain data. The free surface was considered to be flat at the beginning of the simulation, and the water level was set to $517 \mathrm{~m}$ a.s.l.

Before the simulation, a sensitivity analysis was conducted to evaluate the influence of some of the parameters on the model results (i.e., horizontal diffusivity and water albedo for shortwave radiation). This analysis was performed using the perturbation parameter method (Schladow and Hamilton, 1996). In this case, we changed the water albedo and the horizontal diffusivity to $\pm 10 \%$ of the assigned values. The ELCOM results were validated using the water temperature data acquired hourly by the thermistor chains at stations $\mathrm{S} 1$ and S2 and the water level data that were measured daily at the dam. The validation was performed using four methods: (1) a visual comparison of the positions of the isotherms obtained using field data and those estimated by the model; (2) error analysis of simulated water temperatures at different depths; (3) error analysis of the simulated water level near the dam; and (4) comparison of the sensible and latent heat fluxes simulated by the model and those obtained by Curtarelli et al. (2013b) using the MODIS WST product.

\subsection{Diurnal mixed layer dynamics analysis}

The dynamics of the DML during the study period and its response to the cold front passages were analyzed through the Wedderburn number and the approach described by Imberger (1985) and Read et al. (2011). The Wedderburn num- ber was computed in the following way:

$$
W=\frac{g^{\prime} h^{2}}{L u_{\mathrm{W}}^{* 2}}
$$

where $g^{\prime}$ is the reduced gravitational acceleration due to the density jump across the base of the DML and was computed using the density profiles simulated by ELCOM $\left(\mathrm{m} \mathrm{s}^{-2}\right), h$ is the depth of DML (m), $L$ is the basin length scale in the direction of the wind $(\sim 7000 \mathrm{~m})$ and $u_{\mathrm{w}}^{*}$ is the water shear velocity scale $\left(\mathrm{m} \mathrm{s}^{-1}\right)$. The DML depth, $h$, was defined as the first depth where the temperature difference was $0.02{ }^{\circ} \mathrm{C}$ relative to the surface temperature located at $0.1 \mathrm{~m}$ (MacIntyre et al., 2002) and was computed using the temperature profile simulated by ELCOM. The velocity scale associated with the generation of mechanical TKE was evaluated using the water shear velocity, $u_{\mathrm{w}}^{*}$, defined as (Imberger, 1985)

$u_{\mathrm{w}}^{*}=\left(\frac{\tau}{\rho_{\mathrm{w}}}\right)^{1 / 2}$,

where $\tau$ is the surface wind stress $(\mathrm{Pa})$ and $\rho_{\mathrm{W}}$ is the surface water density simulated by ELCOM $\left(\mathrm{kg} \mathrm{m}^{-3}\right)$. The velocity scale associated with the convective overturn was evaluated using the penetrative convection velocity, $w *$, defined as (Imberger, 1985)

$w_{*}=(B h)^{1 / 3}$,

where $B$ is the buoyancy flux $\left(\mathrm{m}^{2} \mathrm{~s}^{-3}\right)$ given by

$B=\frac{g \alpha H^{*}}{C_{\mathrm{pw}} \rho_{\mathrm{w}}}$,

where $g$ is the gravitational acceleration (i.e., $9.8 \mathrm{~m} \mathrm{~s}^{-2}$ ), $\alpha$ is the water thermal expansion coefficient in the range of 20 $30^{\circ} \mathrm{C}$ as estimated by MacIntyre et al. (2002), $C_{\mathrm{pw}}$ is the specific heat of water (ie., $4186 \mathrm{~J} \mathrm{~kg}^{-1} \mathrm{~K}^{-1}$ ) and $H^{*}$ is the effective surface heat flux $\left(\mathrm{W} \mathrm{m}^{-2}\right)$ calculated as a function of the surface heat balance, $h$ and $\eta_{\mathrm{a}}$ (Imberger, 1985). The mechanical energy flux into the DML, $F_{q}$, was obtained using the following equation (Imberger, 1985):

$F_{q}=0.5\left(w_{*}^{3}+C_{n}^{3} u w^{* 3}\right)$,

where $C_{n}$ is a constant (i.e., 1.33).

\section{Results}

\subsection{Meteorological forcing at the Itumbiara Reservoir}

A marked diel pattern was observed for air temperature, shortwave radiation, humidity and wind speed (Fig. 3a-d). As observed in Fig. 3, the meteorological variables measured by SIMA exhibited similar patterns in the different reservoir zones (near-dam and transition zone). However, in 


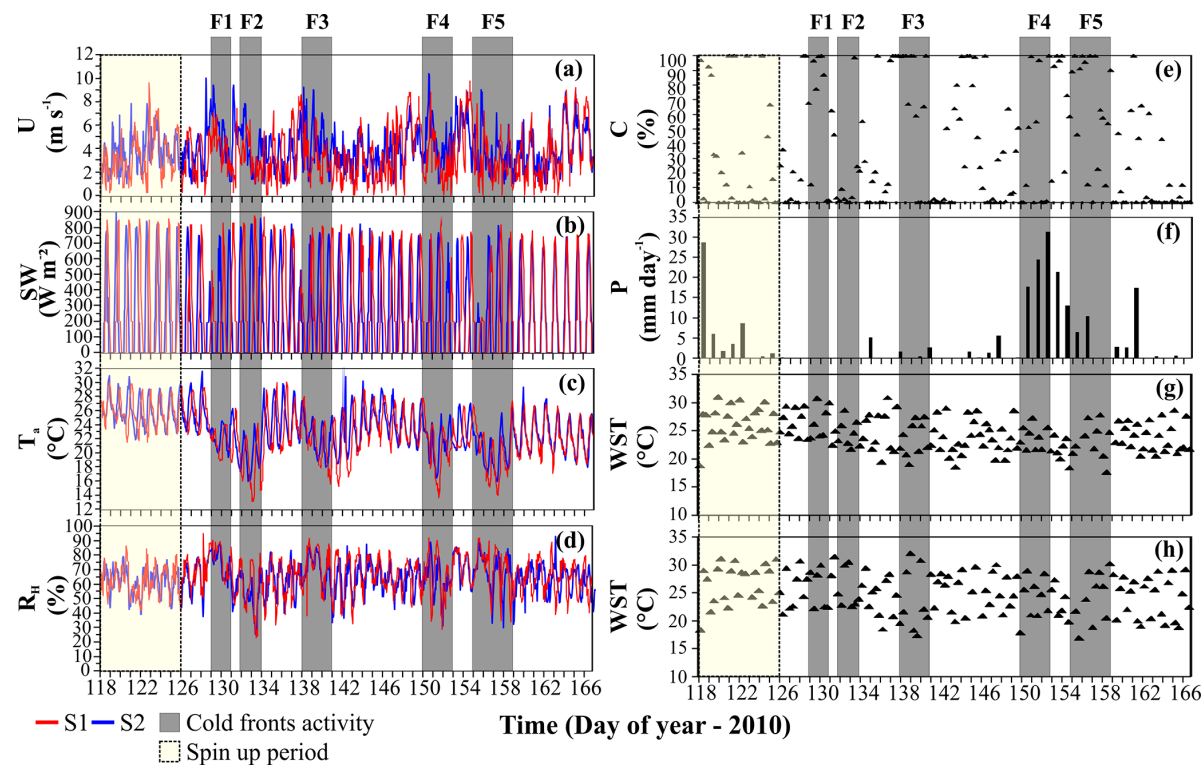

Figure 3. Time series of wind speed (a), shortwave radiation (b), air temperature (c), relative humidity (d), cloud cover (e), precipitation rate (f), WST at the Paranaíba inflow (g) and WST at the Corumbá inflow (h) used to enforce the 3-D hydrodynamic model.

most of the period analyzed, the wind speed (Fig. 3a) was significantly higher $(p<0.01)$ near the dam (mean value of $3.6 \mathrm{~m} \mathrm{~s}^{-1}$ ) than in the transition zone (mean value of $3.0 \mathrm{~m} \mathrm{~s}^{-1}$ ). Moreover, the preferential wind direction showed little difference. Near the dam, the preferential direction was from $\mathrm{E}$ to $\mathrm{W}$, while in the transition zone, the preferential direction was from SE to NW. The air temperature (Fig. 3c) also changed in the different reservoir zones; the air temperature was significantly lower $(p<0.01)$ near the dam (mean value of $22.8^{\circ} \mathrm{C}$ ) than in the transition zone (mean value of $23.3^{\circ} \mathrm{C}$ ). The relative humidity (Fig. $3 \mathrm{~d}$ ) and the shortwave radiation (Fig. 3b) showed statistically equal values in the different reservoir zones; the mean relative humidity for the period was $65 \%$, and the mean incident shortwave radiation was $240 \mathrm{~W} \mathrm{~m}^{-2}$.

On the days when cold fronts did not pass, the air temperature typically ranged from 20 to $30^{\circ} \mathrm{C}$ throughout the day; the lowest temperature was observed at approximately 09:00 LT and the highest value was observed at approximately 18:00 LT. The shortwave radiation peak of approximately $800 \mathrm{~W} \mathrm{~m}^{-2}$ occurred around noon. On average, the humidity ranged from 45 to $75 \%$; higher values were observed during the morning. The lowest humidity was observed during the afternoon at approximately 19:00 LT. The wind speed was higher in the morning and reached $6 \mathrm{~m} \mathrm{~s}^{-1}$ with a preferential direction from the E/SE.

However, on the cold front days, the air temperature decreased and typically ranged from 15 to $22^{\circ} \mathrm{C}$ during the day. Due to the cloudiness associated with the cold front passages over the Itumbiara Reservoir (Fig. 3e), the shortwave radiation peaks were lower during the cold front days; in some cases, the maximum shortwave radiation observed was
$250 \mathrm{~W} \mathrm{~m}^{-2}$. The relative humidity also decreased during the cold front days and reached values of approximately $30 \%$. The wind speed increased to as high as $9 \mathrm{~m} \mathrm{~s}^{-1}$, and the preferential wind direction changed to the S/SW. Table 2 shows a summary of the weather condition changes that occurred during the cold front passages and the period of cold front activity over the Itumbiara Reservoir. All changes observed in the meteorological variables during the cold front events were statistically significantly $(p<0.01)$ when compared with the prior conditions.

\subsection{Model simulation}

\subsubsection{Sensitivity analysis and validation}

ELCOM had a low sensitivity to the parameters analyzed (i.e., water albedo for shortwave radiation and horizontal diffusivity) for IHR. The differences in the model results for the different values tested were lower than $2.5 \%$. Visually, the model was able to reproduce quite well the evolution of temperature isotherms and the cooling trend of the water column during the period analyzed in both locations (Fig. 4). The model was also able to reproduce the dynamics of the DML throughout the day.

The summary of the error analysis for the simulated temperature (Table 3) showed that for both sampled validation points and depths, the root-mean-square error (RMSE) was lower than $16 \%$ of the range and indicates that ELCOM performed well when predicting the water column temperature. The model performed better in the region near the dam with an average RMSE of $0.34{ }^{\circ} \mathrm{C}(\sim 10 \%$ of the range); the validation point in the river-reservoir transition zone had an 
Table 2. Summary of weather conditions during the cold front passages over the Itumbiara Reservoir. Drop in air temperature $\left(\Delta T_{\mathrm{a}}\right)$, maximum wind intensity $\left(U_{\max }\right)$, preferential wind direction, relative humidity variation $\left(\Delta R_{\mathrm{H}}\right)$ and accumulated precipitation $(P)$.

\begin{tabular}{clrrlrr}
\hline $\begin{array}{c}\text { Cold } \\
\text { front ID }\end{array}$ & Date & $\begin{array}{r}\Delta T_{\mathrm{a}}^{*} \\
\left({ }^{\circ} \mathrm{C}\right)\end{array}$ & $\begin{array}{r}U_{\mathrm{max}} \\
\left(\mathrm{m} \mathrm{s}^{-1}\right)\end{array}$ & $\begin{array}{l}\text { Change in } \\
\text { wind direction }\end{array}$ & $\begin{array}{r}\Delta R_{\mathrm{H}} \\
(\%)\end{array}$ & $\begin{array}{r}P^{* *} \\
(\mathrm{~mm})\end{array}$ \\
\hline F1 & 9 May 2010-10 May 2010 & 5.2 & 7.1 & From E/NE to SW & 30.9 & 0 \\
F2 & 12 May 2010-13 May 2010 & 3.8 & 6.5 & From E/NE to SW & 55.7 & 0 \\
F3 & 18 May 2010-20 May 2010 & 3.4 & 8.6 & From E/NE to S & 54.1 & 4.4 \\
F4 & 30 May 2010-1 July 2010 & 3.1 & 8.8 & From E/NE to S & 63.9 & 73.2 \\
F5 & 4 July 2010-7 July 2010 & 4.3 & 7.2 & From E/NE to S & 57.6 & 16.7 \\
\hline
\end{tabular}

* The drop in the air temperature was computed by the subtraction of daily averaged temperature in the day before the cold front passage and the daily averaged temperature in the coldest day during the cold front activity. ${ }^{* *}$ The values represent the precipitation accumulated during the cold front activity.

Table 3. MAE and RMSE of the simulated temperature at the S1 and S2 stations.

\begin{tabular}{|c|c|c|c|c|c|c|c|c|}
\hline \multirow{2}{*}{$\begin{array}{c}\text { Depth } \\
\text { sampled (m) }\end{array}$} & \multicolumn{4}{|c|}{$\mathrm{S} 1$} & \multicolumn{4}{|c|}{$\mathrm{S} 2$} \\
\hline & $\operatorname{MAE}\left({ }^{\circ} \mathrm{C}\right)$ & $\operatorname{MAE}(\%)$ & $\operatorname{RMSE}\left({ }^{\circ} \mathrm{C}\right)$ & RMSE (\%) & $\operatorname{MAE}\left({ }^{\circ} \mathrm{C}\right)$ & MAE (\%) & $\operatorname{RMSE}\left({ }^{\circ} \mathrm{C}\right)$ & RMSE (\%) \\
\hline 1.5 & 0.29 & 6.71 & 0.32 & 7.41 & - & - & - & - \\
\hline 5.0 & 0.30 & 8.38 & 0.33 & 9.15 & 0.36 & 1.4 & 0.39 & 10.25 \\
\hline 12.0 & 0.27 & 8.06 & 0.30 & 8.85 & 0.36 & 1.42 & 0.39 & 12.04 \\
\hline 20.0 & 0.26 & 8.15 & 0.29 & 8.88 & 0.65 & 2.53 & 0.75 & 26.24 \\
\hline 39.0 & 0.39 & 13.66 & 0.45 & 15.74 & - & - & - & - \\
\hline Average & 0.30 & 8.99 & 0.34 & 10.01 & 0.60 & 2.33 & 0.66 & 13.21 \\
\hline
\end{tabular}

average RMSE of $0.66^{\circ} \mathrm{C}(\sim 13 \%$ of the range). This level of accuracy is consistent with other 3-D modeling studies of lakes (Hodges et al., 2000; Okely et al., 2010).

The error analysis of the simulated water level near the dam also produced favorable results, indicating that the ELCOM model could accurately compute the water balance and represent the reduction in the water level during the simulation period. The mean absolute error (MAE) and RMSE of the simulated water level in the dam were 0.35 and $0.37 \mathrm{~m}$ ( $<3.5 \%$ of the range), respectively. The area-average sensible (Fig. 5a) and latent (Fig. 5b) heat fluxes estimated by the model showed good correlation with the fluxes obtained by Curtarelli et al. (2013b) using the product M*D11A1 $\left(R^{2}>0.88\right)$. The MAE of the simulated sensible and latent heat fluxes were 6 and $148 \mathrm{~W} \mathrm{~m}^{-2}$, respectively. The RMSE of the simulated sensible heat flux was $7 \mathrm{~W} \mathrm{~m}^{-2}$, while the RMSE of the simulated latent heat flux was $168 \mathrm{~W} \mathrm{~m}^{-2}$.

\subsubsection{Heat balance}

All three components of the surface heat fluxes estimated by the model showed a marked diel cycle during the study period (Fig. 6a). The area-average latent heat flux estimated by the model ranged from -492 to $-0.4 \mathrm{~W} \mathrm{~m}^{-2}$, with a mean value of $-181 \mathrm{~W} \mathrm{~m}^{-2}$. At the diel scale, the peak of the latent heat loss generally occurred in the morning between 08:00 and 09:00 LT when the minimum air temperature and maximum wind speed occurred. The lowest value of latent heat loss generally occurred in the afternoon between 15:00 and 16:00 LT when the air temperature increased and the wind speed decreased.

The area-average longwave flux ranged from -15 to $15 \mathrm{~W} \mathrm{~m}^{-2}$, with a mean value of $-72 \mathrm{~W} \mathrm{~m}^{-2}$. Few positive values were observed during the study period; they generally occurred on the days with cold front passages over the IHR. The longwave heat flux showed a diel pattern similar to that of the latent heat flux; the peak longwave heat loss generally occurred at 08:00 LT, and the lowest value of longwave heat loss occurred between 15:00 and 16:00 LT.

The area-average sensible heat flux ranged from -122 to $14 \mathrm{~W} \mathrm{~m}^{-2}$ during the day, with a mean value of $-25 \mathrm{~W} \mathrm{~m}^{-2}$. The positive values were observed, in general, in the afternoon when the air temperature was higher than the WST. The peak of the sensible heat loss occurred between 07:00 and 08:00 LT when the air temperature dropped and the wind speed increased.

The Bowen ratio analysis (Fig. 6b) indicates that the latent heat flux is the main source of turbulent heat loss. The reservoir heat balance (Fig. 6c) was primarily controlled by the shortwave incoming radiation (heat gain) and the latent heat flux (heat loss). Heat gain occurred during the morning and afternoon between 09:00 and 18:00 LT when solar radiation was present. The peak of the heat gain was generally observed at 12:00 LT, which is in phase with the solar radiation signal. The peak of the heat loss generally occurred at 08:00 LT, which coincides with the peak of the 


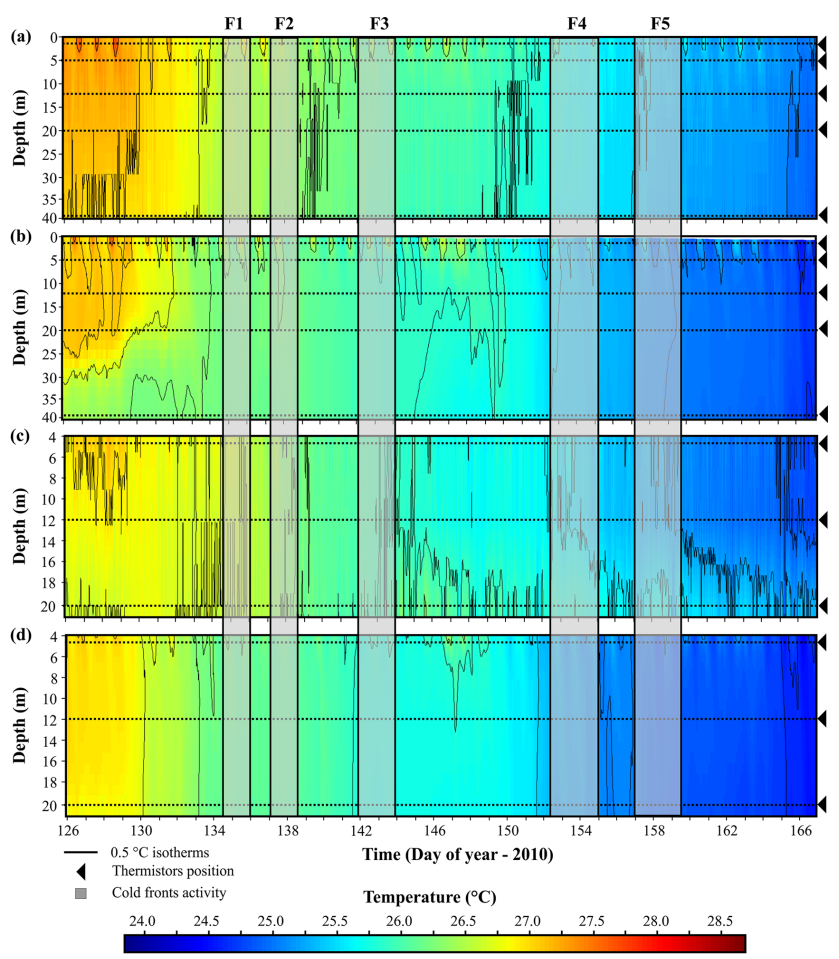

Figure 4. Observed (a) and modeled (b) water column temperature in the region near the dam (station S1), and observed (c) and modeled (d) water column temperature in the transition zone (station S2).
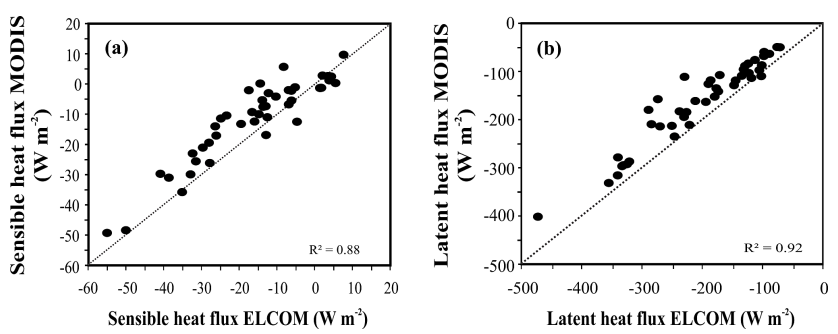

Figure 5. Comparison between MODIS-derived and modeled sensible heat flux (a) and latent heat flux (b).

latent heat loss. The area-average surface heat balance ranged from -638 to $706 \mathrm{~W} \mathrm{~m}^{-2}$, with a mean value of $-48 \mathrm{~W} \mathrm{~m}^{-2}$; thus, the reservoir was losing energy to the atmosphere. Considering a reservoir surface area of $780 \mathrm{~km}^{2}$ and the mean area-average heat flux $\left(-48 \mathrm{~W} \mathrm{~m}^{-2}\right)$, approximately $1.3 \times 10^{17} \mathrm{~J}$ of energy was released to the atmosphere during the simulated period.

\subsubsection{Thermal structure}

The temporal variation of the water column's thermal structure that was predicted by ELCOM along the longitudinal transect (AA') indicates that the main body of the reservoir had weak thermal stratification from the beginning of the

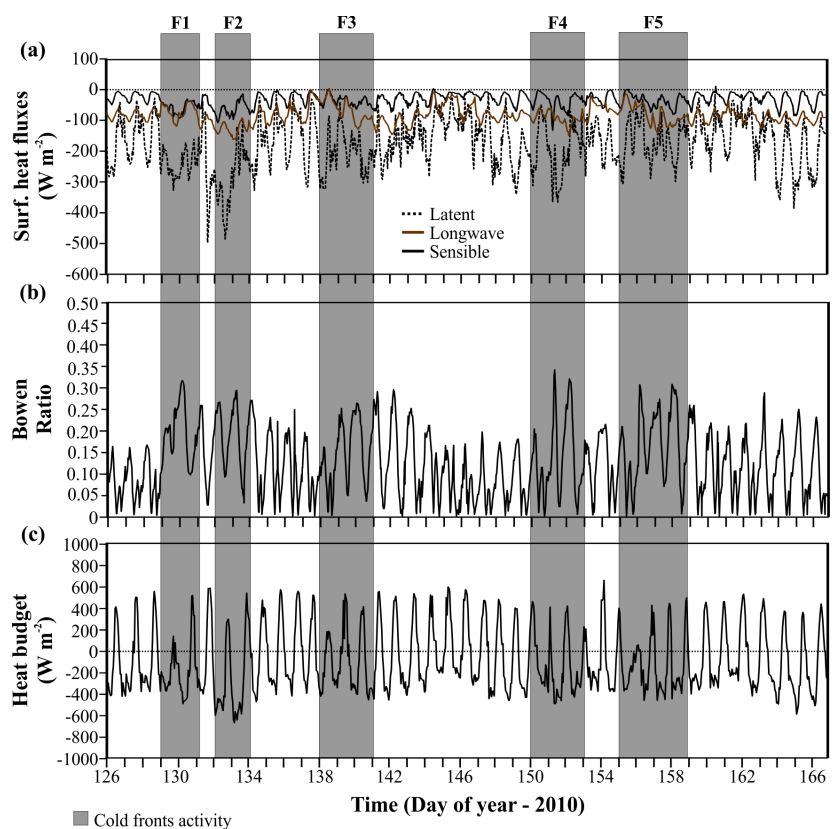

Figure 6. Time series of modeled surface heat flux components (a), Bowen ratio (b) and total heat balance (c).

simulation; a difference of $2{ }^{\circ} \mathrm{C}$ was observed between the surface $\left(27.5^{\circ} \mathrm{C}\right)$ and the bottom $\left(25.5^{\circ} \mathrm{C}\right)$; the water column temperature was approximately $26^{\circ} \mathrm{C}$ (Fig. 7). However, as expected from the heat balance results, the water column of the IHR exhibited a cooling trend during the season and reached values below $23^{\circ} \mathrm{C}$ at the end of the simulation. A thermal gradient was observed in the longitudinal direction in which the main body of the reservoir was typically warmer than the river-reservoir zone $\left(\sim 1^{\circ} \mathrm{C}\right)$. This thermal gradient was enhanced during the simulation period and reached values of approximately $2{ }^{\circ} \mathrm{C}$. In the region near the dam, the water column was completely mixed with a less than $0.5^{\circ} \mathrm{C}$ difference in the temperatures of the surface and of the bottom. The IHR showed a spatial heterogeneous WST with a horizontal temperature gradient towards the center of the reservoir of approximately $4^{\circ} \mathrm{C}$ (Fig. 8). This gradient was more pronounced during the night and early morning when heat loss is higher and the heat budget is negative; however, it persisted throughout the day.

\subsection{Diurnal mixed layer dynamics}

During the study period, the Wedderburn number values ranged from 0 to 152 (Fig. 9a), with a mean value of 0.88 ; these values are indicative of severe mixing between the epilimnion and the hypolimnion and the occurrence of entrainment. The lowest values of $W$ were generally observed during the night and early morning when the heat loss and the wind speed values were highest. The $W$ values tended to increase throughout the day; this trend indicates the detrainment of the mixed layer and the increase of thermal 


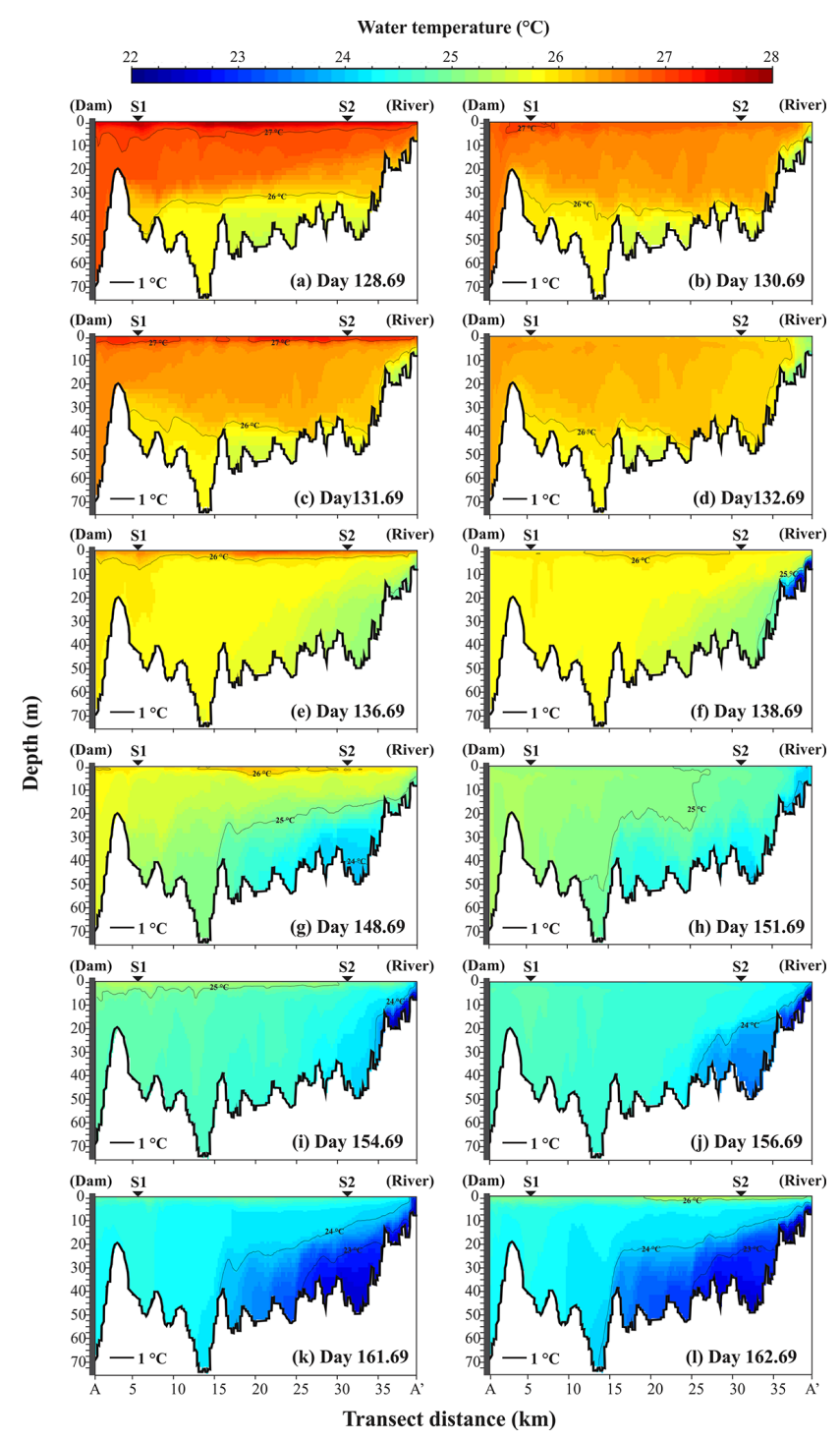

Figure 7. Changes in the thermal structure of the Itumbiara Reservoir along its longitudinal (AA') transect $(\mathbf{a}-\mathbf{l})$. The AA' transect location is shown in Fig. 1.

stratification in the upper part of the water column. The depth of DML (Fig. 9b) ranged from 0.3 to $10 \mathrm{~m}$ during the period, with a mean depth of $4.5 \mathrm{~m}$. The DML dynamics exhibited distinct phases during the day: typically shallower during the day and deepened at night.

The water shear velocity scale ranged from 0 to $1.4 \mathrm{~cm} \mathrm{~s}^{-1}$ with a mean value of $0.51 \mathrm{~cm} \mathrm{~s}^{-1}$ (Fig. 9c), while the penetrative convection velocity scale ranged from 0.04 to $1.5 \mathrm{~cm} \mathrm{~s}^{-1}$ with a mean value of $0.68 \mathrm{~cm} \mathrm{~s}^{-1}$ (Fig. 9d). These two velocity scales exhibited similar behaviors during the day, i.e., higher values during the night and early morning and lower values during the afternoon. The penetrative convection velocity-scale values were higher than water shear velocity-scale all day and indicate that during the simulated

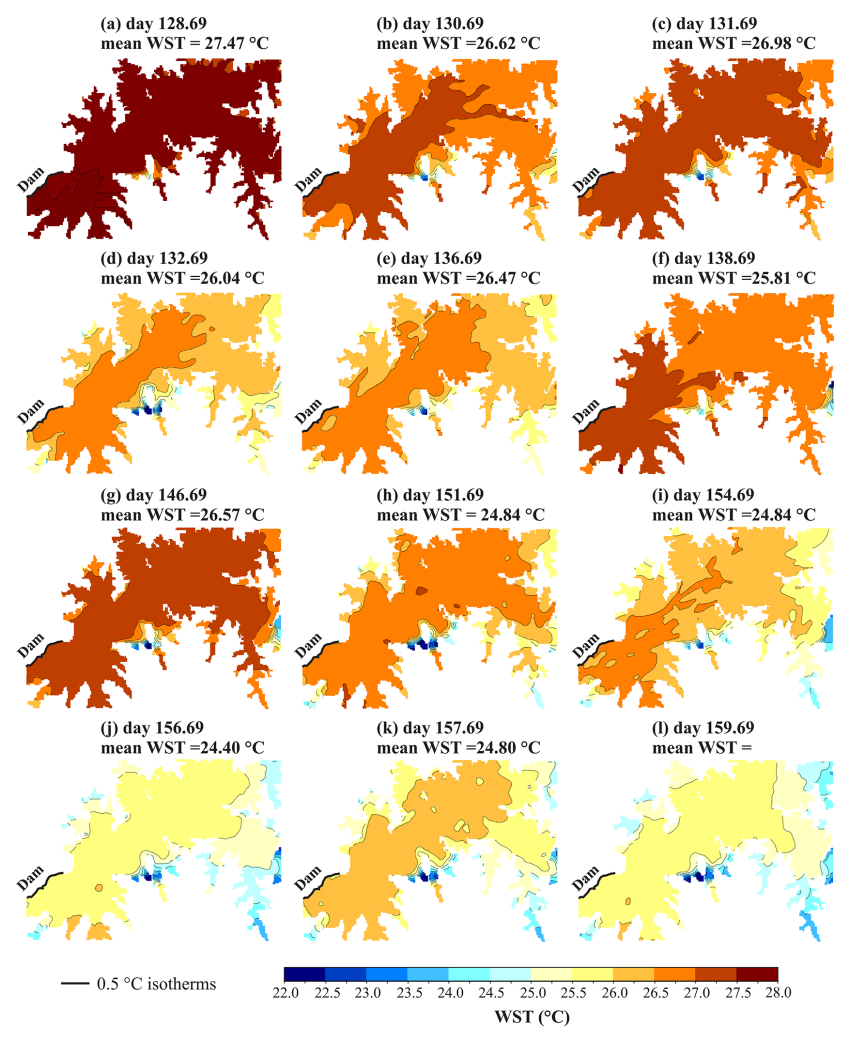

Figure 8. Spatiotemporal variations of WST simulated during the period analyzed $(\mathbf{a}-\mathbf{l})$.

period (beginning of austral winter) most of the TKE available for mixing the water column is generated by convection of the water column.

The energy flux into the DML ranged from $1.32 \times 10^{-9}$ to $3.47 \times 10^{-6} \mathrm{~m}^{3} \mathrm{~s}^{-3}$ with a mean value of $6.25 \times 10^{-7}$ (Fig. 9e). Higher values were typically observed at night and in the morning due to the high wind speed and convection induced by the surface cooling (high buoyancy flux). Lower values were observed during the afternoon and evening due to the low wind speed and weak buoyancy flux. Surface cooling was the main process contributing to the flux of TKE into the DML and accounted for an average of $53 \%$ of the energy input during the day; wind shear is the secondary contributor to the energy flux and accounts for $47 \%$ of the total energy input.

\subsection{Comparison of days with and without cold fronts}

\subsubsection{Heat balance}

We evaluated the impacts of cold fronts on the daily heat balance by averaging the simulated heat balance components for every hour of the days with and without cold front activity during the simulated period (Fig. 10). On the days when cold fronts were absent, the area-average latent heat flux estimated by ELCOM ranged from -115 to $-230 \mathrm{~W} \mathrm{~m}^{-2}$, 




Figure 9. Time series computations of Wedderburn number (a), DML depth (b), water shear velocity scale (c), penetrative entrainment velocity scale (d) and energy input (e).

with a mean value of $-166 \mathrm{~W} \mathrm{~m}^{-2}$ (Fig. 10a). On the cold front days, the area-average latent heat flux increased and ranged from -159 to $-225 \mathrm{~W} \mathrm{~m}^{-2}$, with a mean value of $-194 \mathrm{~W} \mathrm{~m}^{-2}$. The daily mean latent heat loss was significantly higher $(p<0.01)$ on the cold front days than on the days without cold fronts; the daily mean area-average latent heat flux was approximately $16 \%$ higher on the days with cold front activity.

The area-average estimates of the longwave heat flux ranged from -57 to $-103 \mathrm{~W} \mathrm{~m}^{-2}$ during the days without cold fronts (Fig. 10b). However, in contrast to the latent heat flux, the absolute value of the daily mean area-average longwave heat flux was significantly lower $(p<0.01)$ during the cold front days than during the days without cold fronts, i.e., $-80 \mathrm{~W} \mathrm{~m}^{-2}$ (mean value for non-cold-front days) and $-66 \mathrm{~W} \mathrm{~m}^{-2}$ (mean value for cold front days), an approximately $16 \%$ difference. This result can be explained by the increased cloudiness that occurred during the cold front


Figure 10. Impacts of a cold front on the heat flux: (a) latent heat, (b) net longwave, (c) sensible heat and (d) total heat balance.

event, which contributes to the incoming longwave radiation flux, the decreased surface water temperature, and the decreased longwave radiation loss.

The absolute value of the sensible heat flux was significantly higher $(p<0.01)$ on the cold front days than on the days without cold fronts. On the days without cold front passages, the area-average sensible heat flux predicted by ELCOM ranged from -6 to $-46 \mathrm{~W} \mathrm{~m}^{-2}$, with a mean value of $-21 \mathrm{~W} \mathrm{~m}^{-2}$ (Fig. 10c). However, during cold front conditions, the sensible heat flux typically ranged from -24 to $-53 \mathrm{~W} \mathrm{~m}^{-2}$, with a mean value of $-36 \mathrm{~W} \mathrm{~m}^{-2}$, which represents a $77 \%$ increase in the heat loss by the sensible heat flux. For the five cold front passages simulated, the sensible heat fluxes showed similar patterns in which the heat loss magnitude differences were small. The maximum instantaneous sensible heat loss occurred during F4 (see Fig. 6a) when the sensible heat flux reached $-122 \mathrm{~W} \mathrm{~m}^{-2}$ in some reservoir areas. This value is approximately fourfold higher than the maximum sensible heat loss predicted by the model during days without cold fronts.

During the days without cold fronts, the area-average heat balance ranged from -332 to $510 \mathrm{~W} \mathrm{~m}^{-2}$ with a mean value of $-32 \mathrm{~W} \mathrm{~m}^{-2}$. On the cold front days, the heat balance ranged from -332 to $450 \mathrm{~W} \mathrm{~m}^{-2}$ with a mean value of $-87 \mathrm{~W} \mathrm{~m}^{-2}$. As result of the increase in the latent and sensible heat loss and the decrease in the shortwave incident radiation during the cold front days, the IHR lost nearly twofold more energy on a cold front day than on a day without a cold front (Fig. 10d). The maximum heat loss occurred on 12 May at 19:00 LT during F2 (see Fig. 6a) when the heat budget was $-611 \mathrm{~W} \mathrm{~m}^{-2}$. This value is approximately twofold higher than the maximum instantaneous heat loss predicted by ELCOM during a non-cold-front day. 

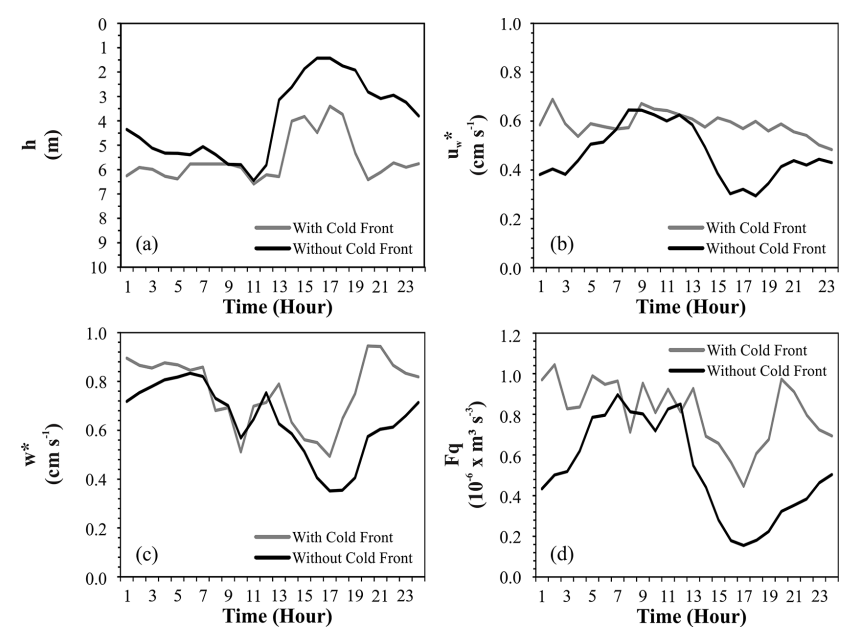

Figure 11. Impacts of a cold front on the DML dynamics: (a) DML depth, (b) water shear velocity scale, (c) penetrative entrainment velocity scale and (d) energy flux into the DML.

\subsubsection{Diurnal mixed layer dynamics}

The impacts of the cold fronts on the DML dynamics were evaluated in the same way as the heat balance, by averaging the computed variables for every hour of the days with and without cold front activity (Fig. 11). Typically, on the days without cold front activity, the DML depth ranged from 1.4 to $6.4 \mathrm{~m}$ with a mean depth of $3.9 \mathrm{~m}$ (Fig. 11a). However, on the days with cold front activity, the DML depth ranged from 3.4 to $6.6 \mathrm{~m}$ with a mean depth of $5.6 \mathrm{~m}$, which represents an increase of $41 \%$ in the mean DML depth. This finding can be related to the effective heat flux and wind speed, which were generally 39 and $45 \%$ higher (in absolute values), respectively, on the days with cold front passages; the effective heat flux and wind speed reached daily mean values of -166 and $5.5 \mathrm{~m} \mathrm{~s}^{-1}$, respectively, under cold front passage conditions.

The water shear and penetrative entrainment velocity scales were typically higher on the days with cold front passages (Fig. 11b, c); the values were approximately 26 and $19 \%$ higher, respectively, compared to the days without cold front passages. Hence, the energy input into the DML increased by approximately $55 \%$ on the days with cold front events over the IHR; under these conditions, the $F_{q}$ ranged from $4.46 \times 10^{-7}$ to $1.04 \times 10^{-6} \mathrm{~m}^{3} \mathrm{~s}^{-3}$ with a mean daily value of $8.11 \times 10^{-7} \mathrm{~m}^{3} \mathrm{~s}^{-3}$ (Fig. 11d). For the days without cold front passages, the penetrative entrainment was responsible for approximately $53 \%$ of the energy input into the DML generated by the stirring mechanisms $\left(\sim 2.76 \times 10^{-7} \mathrm{~m}^{3} \mathrm{~s}^{-3}\right)$, while the water shear was responsible for $47 \%\left(\sim 2.48 \times 10^{-7} \mathrm{~m}^{3} \mathrm{~s}^{-3}\right)$. However, on the days with cold front passages, the contribution of each term was inverted and the water shear was the main mechanism governing the energy input into the DML $(\sim 52 \%)$, approximately $4.18 \times 10^{-7} \mathrm{~m}^{3} \mathrm{~s}^{-3}$ (mean daily value). The timescale of mixing due to the penetrative entrainment $\left(h / w^{*}\right)$ and water shear $\left(h / u_{w}^{*}\right)$ showed a distinct behavior under cold front conditions; the penetrative entrainment timescale increased (from 8 to $11 \mathrm{~min}$ ), while the water shear timescale decreased (from 30 to $20 \mathrm{~min}$ ). This finding indicates that the increase of wind speed during the cold front passage is one of the main factors influencing the changes in the DML dynamics.

\section{Discussion}

\subsection{Increase of latent and sensible heat loss induced by cold front passage}

The cooling of the IHR is a natural process that occurs every year from May to August (fall and winter in the Southern Hemisphere). According to Alcântara et al. (2010b), this process is mainly controlled by the solar declination and the changes in the weather conditions throughout the year. As a consequence, the heat balance between the water and the atmosphere changes, and the water column of the IHR cools. However, our results showed that the successive passages of cold fronts in a short time period also exert influence on the cooling phase of the IHR to enhance the release of sensible and latent heat to the atmosphere.

As shown in Sect. 4.1, the cold front activity over the IHR changes the weather characteristics and impacts the heat balance of the reservoir. The increase of latent and sensible heat loss and decrease of net longwave radiation during cold front activity were also observed in lakes and reservoirs located in the temperate (Blanken et al., 2000; Liu et al., 2009, 2011) and polar regions (MacIntyre et al., 2009). Liu et al. (2009) showed that during a cold front event, the latent and sensible heat fluxes can reach values of approximately -450 and $-250 \mathrm{~W} \mathrm{~m}^{-2}$, respectively, in the Ross Barnett Reservoir near Ridgeland, Mississippi, USA; these values are $10 \%$ lower and $100 \%$ higher, respectively, than the maximum values simulated in the IHR. In the polar region, the latent heat flux can reach values between -100 and $-150 \mathrm{~W} \mathrm{~m}^{-2}$ (MacIntyre et al., 2009), which are approximately $300 \%$ lower than the maximum value predicted in the Itumbiara Reservoir. However, the sensible heat loss is approximately $25 \%$ higher in the polar region. The differences observed in the amounts of energy released during cold front passages over reservoirs in the distinct regions may be attributed to the differences in air mass characteristics and the stability of the atmosphere. In the temperate and polar regions, unstable and stable $\mathrm{ABL}$ conditions alternate, while the ABL over the Itumbiara Reservoir was unstable during $98 \%$ of the study period. 


\subsection{Impacts of cold fronts on the differential cooling process}

Results obtained by Alcântara et al. (2010b) showed that during May and June, the differential cooling process creates a weak horizontal temperature gradient in the IHR. This weak temperature gradient between the littoral and pelagic zones is not able to generate density currents. However, our results showed that during the cold front days, the differential cooling process is intensified and the temperature gradient between the littoral and pelagic zones tends to be higher than the gradient during the days prior to the cold front activity (Fig. 9).

This finding can be explained by the spatial variability of heat budget components. Recently, Curtarelli et al. (2013b) showed that when a cold front moves over the IHR, the sensible and latent heat fluxes are higher in the littoral zone than in the pelagic zone; thus, intensive cooling occurs in the littoral zone and enhances the horizontal temperature gradient. According to these authors, the heat loss intensification can be separated into two periods: first, during the cold front passage, when the wind speed increases and the air temperature decreases; second, after the cold front passage, when the air humidity decreases.

The increased horizontal temperature gradient observed during and after the cold front activity was responsible for promoting baroclinic instability (Wells and Sherman, 2001) and creating density currents after the cold front activity. The velocity of the currents reached values of approximately $16 \mathrm{~cm} \mathrm{~s}^{-1}$ after a cold front passage, and a large volume of water was transported from the littoral zone to the pelagic zone in a relatively short time period. This type of transport plays an important role in the biological and chemical processes of the reservoir (Imboden, 1990), for example, exporting nutrients and oxygen from shallow to deep regions. Studies conducted in other Brazilian reservoirs showed that there is a trend of algal bloom occurrence in the days after a cold front passage (Tundisi et al., 2004; Morais et al., 2010) due to the nutrient input by density currents.

\subsection{Possible impacts of cold front passages on the IHR water quality}

As we showed previously, the passage of a cold front over the IHR significantly changes the region's heat balance (Fig. 10) and DML dynamics (Fig. 11). Hence, changes are expected in the IHR water quality and ecological dynamics. According to Tundisi et al. (2010), the water column mixing induced by the passage of cold fronts can impact phytoplankton succession. Moreover, some studies (e.g., Eugster et al., 2003) showed that there are strong and significant differences between greenhouse gas (GHG) emissions observed during nonconvective and convective conditions within lakes.

The results of this study relate to the conclusions of Eugster et al. (2003) and Tundisi et al. (2010), who indicate that cold front passages are important events controlling the water quality and GHG emissions in the IHR, mainly during the austral winter when the cold front frequency is higher. The complete water column mixing and differential cooling intensification induced by cold front passages may be the key physical processes driving the ecological dynamics of the IHR. Therefore, further studies of water quality and GHG emissions at the IHR must consider the effects of this meteorological phenomenon.

\section{Conclusions}

In this study, we investigated the impacts of winter cold front passages on the heat balance and diurnal mixed layer dynamics of a large tropical hydroelectric reservoir located in central Brazil. The main conclusions are as follows.

The main changes observed in the meteorological conditions during a cold front passage over the IHR are an increase in the wind speed and decreases in the air temperature and relative humidity. However, the magnitude of these changes depends on the intensity of the cold front. In response to the changes in the weather conditions, the IHR heat balance is substantially altered under cold front conditions. During the cold front days, the heat loss can be two- or threefold greater than that during the non-cold-front days.

The intensification of the differential cooling process during the cold front activity is responsible for generating a strong horizontal temperature gradient towards the center of the reservoir $\left(\sim 8^{\circ} \mathrm{C}\right)$. In the days after the passage, density currents are responsible for exporting a large volume from the littoral to the pelagic zone. This can be a key process controlling the evasion of greenhouse gases in tropical reservoirs subject to cold front activity.

The DML dynamics show two distinct behaviors during the winter, depending on the presence/absence of cold fronts. The occurrence of cold fronts over the IHR contributes to deepening the DML, which can reach a depth of approximately $5 \mathrm{~m}$ during the days with cold front activity. The water shear was the main mechanism governing the DML dynamics in the IHR during the occurrence of a cold front event.

Our results indicate that cold fronts are among the main meteorological disturbances driving the physical processes within hydroelectric reservoirs in tropical South America during the winter. Hence, the cold front activity over these aquatic systems may have several implications for the water quality. Therefore, further studies are needed to better understand and quantify the effects of cold front events on the reservoirs' ecological and biogeochemical processes, such as primary production and greenhouse gas evasion.

Additionally, the results of this study imply that future potential changes in cold front activities (e.g., intensity, frequency, and duration) as a result of climate variability can lead to significant restructuring of the regional energy 
and hydrological balances in tropical South America, where several hydroelectric reservoirs are located.

Acknowledgements. This work was supported by the São Paulo Research Foundation (FAPESP, grants 2007/08103-2 and 2010/15075-8), INCT for Climate Change (CNPq 5737797/2008 and FAPESP 08/57719-9) and the Eletrobras-Furnas company. The authors wish to thank Arcilan Trevenzoli Assireu, Felipe Siqueira Pacheco and Joaquim Antônio Dionísio Leão for assisting with the field campaign; Igor Ogashawara for helping to improve the manuscript; the anonymous reviewers and Matthew Hipsey for the suggestions and comments about the manuscript; and the Center for Water Research (CWR) and its director, Jörg Imberger, for making ELCOM available for this study. The first author is grateful to CAPES for the M.Sc. fellowship.

Edited by: M. Hipsey

\section{References}

Ackerman, S. A., Strabala, K. I., Menzel, W. P., Frey, R. A., Moeller, C. C., and Gumley, L. E.: Discriminating clear-sky from clouds with MODIS, J. Geophys. Res., 103, 32141-32173, 1998.

Alcântara, E. H., Bonnet, M. P., Assireu, A. T., Stech, J. L., Novo, E. M. L. M., and Lorenzzetti, J. A.: On the water thermal response to the passage of cold fronts: initial results for Itumbiara reservoir (Brazil), Hydrol. Earth Syst. Sci. Discuss., 7, 9437-9465, doi:10.5194/hessd-7-9437-2010, 2010a.

Alcântara, E. H., Stech, J. L., Lorenzzetti, J. A., Bonnet, M.-P., Casamitjana, X., Assireu, A. T., and Novo, E. M. L. M.: Remote sensing of water surface temperature and heat flux over a tropical hydroelectric reservoir, Remote Sens. Environ., 114, 2651-2665, 2010b.

Alcântara, H., Curtarelli, M., Ogashawara, I., Stech, J., and Souza, A.: A system for environmental monitoring of hydroelectric reservoirs in Brazil, Ambi-Agua, 8, 6-17, 2013.

Bailey, T. C. and Gatrell, A. C.: Interactive Spatial Data Analysis. Prentice Hall, Harlow, 1995.

Blanken, P. D., Rouse, W. R., Culf, A. D., Spence, C., Boudreau, L. D., Jasper, J. N., Kochtubadja, B., Schertzer, W. M., Marsh, P., and Verseghy, D.: Eddy covariance measurements of evaporation from Great Slave Lake, Northwest Territories, Canada, Water Resour. Res., 36, 1069-1077, 2000.

Bonnet, M.-P. and Wessen, K.: ELMO, a 3-D water quality model for nutrients and chlorophyll: first application on a lacustrine ecosystem, Ecol. Model., 141, 19-33, 2001.

Casulli, V. and Cattani, E.: Stability, accuracy and efficiency of a semi-implicit method for three-dimensional shallow water flow, Comput. Math. Applic., 27, 99-112, 1994.

Casulli, V. and Cheng, R. T.: Semi-implicit finite difference methods for three-dimensional shallow water flow, Int. J. Numer. Meth. Fluids., 15, 629-648, 1992.

Coe, M. T.: A linked global model of terrestrial hydrological processes: Simulation of modern rivers, lakes, and wetlands, J. Geophys. Res., 103, 8885-8899, 1998
Curtarelli, M. P.: Study of the influence of cold fronts on circulation and stratification and mixing processes in Itumbiara reservoir (GO): A hydrodynamic modelling and remote sensing approach, M.Sc. thesis, National Institute for Space Research, 2012.

Curtarelli, M. P., Alcântara, E. H., Rennó, Assireu, A. T., Bonnet, M.-P., and Stech, J. L.: Modelling the surface circulation and thermal structure of a tropical reservoir using three-dimensional hydrodynamic lake model and remote-sensing data, Water Environ. J., 1-10, doi:10.1111/wej.12066, in press, 2013a.

Curtarelli, M. P., Alcântara, E. H., Rennó, C., and Stech, J. L.: Effects of cold fronts on MODIS-derived sensible and latent heat fluxes in Itumbiara reservoir (Central Brazil), Adv. Space Res., 52, 1668-1677, 2013b.

Curtarelli, M. P., Ogashawara, I., Alcântara, E., and Stech, J. L.: Coupling remote sensing bio-optical and three-dimensional hydrodynamic modeling to study the phytoplankton dynamics in a tropical hydroelectric reservoir, Remote Sens. Environ., 1-14, doi:10.1016/j.rse.2014.06.013, in press, 2014.

Eugster, W., Kling, G., Jonas, T., McFadden, J. P., Wüest, A., MacIntyre, S., and Chapin, F. S. III: $\mathrm{CO}_{2}$ exchange between air and water in an Arctic Alaskan and midlatitude Swiss lake: importance of convective mixing, J. Geophys. Res., 108, 4362, doi:10.1029/2002JD002653, 2003.

Fischer, H. B., List, E. G., Koh, R. C. Y., Imberger, J., and Brooks, N. H.: Mixing in Inland and Coastal Waters. Academic Press, San Diego, 1979.

Garreaud, R. D.: Cold air incursions over subtropical South America: Mean structure and dynamics, Mon. Weather Rev., 128, 2544-2559, 2000.

Hicks, B. B. L.: A procedure for the formulation of bulk transfer coefficients over water, Bound-Lay. Meteorol., 8, 515-524, 1975.

Hodges, B. R. and Dallimore, C.: Estuary, Lake and Coastal Ocean Model: ELCOM v2.2 Science Manual. Centre for Water Research, Perth, 2010.

Hodges, B. R., Imberger, J., Saggio, A., and Winters, K. B.: Modeling basin-scale internal waves in a stratified lake, Limnol. Oceanogr., 45, 1603-1620, 2000.

Hodges, B. R., Laval, B., and Wadzuk, B. M.: Numerical error assessment and a temporal horizon for internal waves in a hydrostatic model, Ocean Modell., 13, 44-64, 2006.

Huffman, G. J., Alder, R. F., Bolvin, D. T., Gu, G., Nelkin, E. J., Bowman, K. P., Hong, Y., Stocker, E. F., and Wolf, D. B.: The TRMM Multisatellite Precipitation Analysis (TMPA): quasi-global, multiyear, combined-sensor precipitation estimates at fine scales, J. Hydrometeorol., 8, 38-55, 2007.

Imberger, J.: The diurnal mixed layer, Limnol. Oceanogr., 30, 737$770,1985$.

Imberger, J. and Patterson, J. C.: Physical limnology, Adv. App. Mech., 27, 303-475, 1989.

Imboden, D. M.: Mixing and transport in lake: mechanisms and ecological relevance, in: Large lakes: ecological structure and function, edited by: Tilzer, M. M. and Serruya, C., Springer-Verlag, Berlin, 1990. 
Justice, C. O., Vermote, E., Townshend, J. R. G., Defries, R., Roy, D. P., Hall, D. K., Solomonson, V. V., Privette,J. L., Riggs, G., Strahler, A.,Lucht, W., Myneni, R. B., Knyazikhin, Y., Running, S. W., Nemani, R. R., Wan,Z., Huete,A. R., van Leeuwen, W., Wolfe, R. E., Giglio, L., Muller, J.-P., Lewis, P., and Barnsley, M. J.: The Moderate Resolution Imaging Spectroradiometer (MODIS): Land Remote Sensing for Global Change Research, IEEE Trans. Geosci. Remote Sens., 36, 1228-1247, 1998.

Kummerow, C., Barnes, W., Kozu, T., Shiue J. and Simpson J.: The Tropical Rainfall Measuring Mission (TRMM) sensor package, J. Atmos. Ocean. Technol., 15, 809-817, 1998.

León, L. F., Lam, D. C. L., Schertzer, W. M., Swayne, D. A., and Imberger, J.: Towards coupling a 3D hydrodynamic lake model with the Canadian Regional Climate Model: Simulation on Great Slave Lake, Environ. Modell. Softw., 22, 787-796, 2007.

Leonard, B. P.: The ULTIMATE conservative difference scheme applied to unsteady one-dimensional advection, Comput. Method. Appl. M., 88, 17-74, 1991.

Liu, H., Zhang, Y., Liu, S., Jiang, H., Sheng, L., and Williams, Q. L.: Eddy covariance measurements of surface energy budget and evaporation in a cool season over southern open water in Mississippi, J. Geophys. Res., 114, 1-13, 2009.

Liu, H., Blanken, P. D., Weidinger, T., Nordbo, A., and Vesala, T. Variability in cold front activities modulating cool-season evaporation from a southern inland water in the USA, Environ. Res. Lett., 6, 1-8, 2011.

MacIntyre, S., Flynn, K. M., Jellison, R., and Romero, J. R.: Boundary mixing and nutrient fluxes in Mono Lake, California, Limnol. Oceanogr., 44, 512-529, 1999.

MacIntyre, S., Romero, J. R., and Kling, G. W.: Spatial-temporal variability in surface layer deepening and lateral advection in an embayment of Lake Victoria, East Africa, Limnol. Oceanogr., 47, 656-671, 2002.

MacIntyre, S., Fram, J. P., Kushner, P. J., Bettez, N. D., O’Brien, W. J., Hobbie, J. E., and Kling, G. W.: Climate-related variations in mixing dynamics in an Alaskan arctic lake, Limnol. Oceanogr., 54, 2401-2417, 2009.

Marengo, J. A., Ambrizzi, T., Kiladis, G., and Liebmann, B.: Upperair wave trains over the Pacific Ocean and the wintertime cold surges in tropical-subtropical South America leading to freezes in Southern and Southeaster Brazil, Theor. Appl. Climatol., 73, 223-242, 2002.

Merwade, V.: Effect of spatial trends on interpolation of river bathymetry, J. Hydrol., 371, 169-181, 2009.

Morais, M. A., Castro, W. A. C., and Tundisi, J. G., Climatology of cold fronts over the Metropolitan Region of São Paulo (MRSP) and their influence in the limnology of water supply reservoirs, Braz. J. Meteorol., 25, 205-217, 2010.

Okely, P., Imberger, J., and Antenucci, J. P.: Processes affecting horizontal mixing and dispersion in Winam Gulf, Lake Victoria, Limnol. Oceanogr., 55, 1865-1880, 2010.

Pacheco, F. S., Assireu, A. T., and Roland, F.: Drifters tracked by satellite applied to freshwater ecosystems: study case in Manso Reservoir. Parêntese, São José dos Campos, 2011.

Peel, M. C., Finlayson, B. L., and McMahon, T. A.: Updated world map of the Köppen-Geiger climate classification, Hydrol. Earth Syst. Sci., 11, 1633-1644, doi:10.5194/hess-11-16332007, 2007.
Rayner, K. N.: Diurnal energetics of a reservoir surface layer, M.Sc. thesis, University of Western Australia, 1981.

Read, J. S., Hamilton, D. P., Jones, I. D., Muraoka, K., Winslow, L. A., Ryan, K., Wu, C. H., and Gaiser, E.: Derivation of lake mixing and stratification indices from high-resolution lake buoy data, Environ. Model. Soft., 11, 1325-1336, 2011.

Rueda, F. J. and MacIntyre, S.: Flow paths and spatial heterogeneity of stream inflows in a small multibasin lake, Limnol. Oceanogr., 54, 2041-2057. 2009.

Schladow, S. G. and Hamilton, D. P.: Prediction of water quality in lakes and reservoirs: Part II - Model calibration, sensitivity analysis and application, Ecol. Model., 96, 111-123, 1997.

Serra, T., Vidal, J., Casamitjana, X., Soler, M., and Colomer, J.: The role of surface vertical mixing in phytoplankton distribution in a stratified reservoir, Limnol. Oceanogr., 52, 1-17, 2007.

Setlinger, G. I., Hook, S. J., and Laval, B.: Sub-pixel water temperature estimation from thermal-infrared imagery using vectorized features, Remote Sens. Environ., 112, 1678-1688, 2008.

Slater, P. N.: Remote Sensing: optics and optical systems, AddisonWesley, Reading, 1980.

Spiegel, R. H. and Imberger, J.: The classification of mixed-layer dynamics in lakes of small to medium size, J. Phys. Oceanogr., 10, 1104-1121, 1980.

Stech, J. L. and Lorenzzetti, J. A.: The Response of the south Brazil bight to the passage of wintertime cold fronts, J. Geophys. Res. 97C6, 9507-9520, 1992.

Stech, J. L., Lima, I. B. T., Novo, E. M. L. M., Silva, C. M., Assireu, A. T., Lorenzzetti, J. A., Carvalho, J. C., Barbosa, C. C. F., and Rosa, R. R.: Telemetric monitoring system for meteorological and limnological data acquisition, Verh. Internat. Verein. Limnol., 29, 1747-1750, 2006.

Tundisi, J. G., Matsumura-Tundisi, T., Arantes Junior, J. D., Tundisi, J. E. M., Manzini, N. F., and Ducrot, R.: The response of Carlos Botelho (Lobo, Broa) reservoir to the passage of cold fronts as reflected by physical, chemical, and biological variables, Braz. J. Biol., 64, 177-186, 2004.

Tundisi, J. L., Matsumura-Tundisi, T., Pereira, K. C., Luzia, A. P., Passerini, M. D., Chiba, W. A. C., Morais, M. A., and Sebastien, N. Y.: Cold fronts and reservoir limnology: an integrated approach towards the ecologicl dynamics of freshwater ecosystems, J. Baz. Biol., 70, 815-824, 2010.

Verburg, P. and Antenucci, J. P.: Persistent unstable atmospheric boundary layer enhances sensible and latent heat loss in a tropical great lake: Lake Tanganyika, J. Geophys. Res., 115, 1-13, 2010.

Vidal, J., Rueda, F. J., and Casamitjana, X.: The seasonal evolution of high vertical-mode internal waves in a deep reservoir, Limnol. Oceanogr., 52, 2656-2667, 2007.

Wan, Z.: New refinements and validation of the MODIS landsurface temperature/emissivity products, Remote Sens. Environ., 12, 59-74, 2008.

Wan, Z. and Dozier, J.: A generalized split-window algorithm for retrieving land-surface temperature from space, IEEE Trans. Geosci. Remote Sens., 34, 892-905. 1996.

Wells, M. G. and Sherman, B.: Stratification produced by surface cooling in lakes with significant shallow regions, Limnol. Oceanogr., 46, 1747-1759, 2001.

Wüest, A. and Lorke, A.: Small-scale hydrodynamics, Annu. Rev. Fluid Mech., 35, 373-412, 2003. 